\title{
Criminologie
}

\section{Ce soir au Grand Guignol : l'étrangleur de Boston}

\section{Pierre Mackay}

Volume 16, numéro 1, 1983

La peur du crime

URI : https://id.erudit.org/iderudit/017175ar

DOI : https://doi.org/10.7202/017175ar

Aller au sommaire du numéro

Éditeur(s)

Les Presses de l'Université de Montréal

ISSN

0316-0041 (imprimé)

1492-1367 (numérique)

Découvrir la revue

Citer ce document

Mackay, P. (1983). Ce soir au Grand Guignol : l'étrangleur de Boston.

Criminologie, 16(1), 105-106. https://doi.org/10.7202/017175ar d'utilisation que vous pouvez consulter en ligne.

https://apropos.erudit.org/fr/usagers/politique-dutilisation/ 


\section{CE SOIR AU GRAND GUIGNOL : L'ÉTRANGLEUR DE BOSTON Pierre Mackay*}

On a beaucoup parlé dans ce numéro de la revue Criminologie des victimes, des agresseurs et des policiers. Acteurs du drame criminel et de la peur qu'il génère, ils n'apparaissent, à la réflexion, que comme la partie visible d'une scène dont les coulisses grouillent de monde.

Tout de suite à l'entrée, au guichet pour ainsi dire, un monde industrieux, "assure " littéralement le public que s'il paie bien, s'il se protège, il n'aura pas peur : qu'il verrouille bien ses portes, qu'il se fortifie dans des H.S.B. ${ }^{1}$, qu'il engage des gardes privés, il pourra jouir du spectacle en toute "sécurité et liberté ". S'il est victime, il sera remboursé.

À la régie, pendant ce temps, on fixe la "politique " du spectacle. Le spectacle se vend bien, on en parle. Régisseurs élus, discours de circonstance. On nous promet que les lois et les règles de l'art seront sévères. Les coupables seront châtiés durement, le spectacle doit bien se terminer. Les bons sont les bons, les méchants sont les méchants, c'est la vie, comme on dit au théâtre.

Toute l'industrie culturelle, la grande, la petite et la jaune - surtout la jaune - fait écho au thème. L'horrible et le macabre sont mis au goût du jour.

En coulisse, certains amateurs suivent tout cela en anges gardiens ${ }^{2}$. Ils voudraient rehausser la qualité du spectacle, en infléchir le dénouement. Peut-être voudront-ils un jour devenir régisseurs à la place des régisseurs?

Dans la salle, toute une foule se bouscule. Les émotions ne seront pas que théâtrales, car chaque soir, on choisit une ou deux spectatrices pour monter sur la scène. Elles viennent souvent du balcon ou des places réservées aux groupes de l'âge d'or. Montréal.

* Professeur au Département des Sciences juridiques, Université du Québec à

1. High Security Building.

2. À New York, depuis 1978, l'organisation bénévole privée "guardian angels" vise à assurer la protection du public dans le métro. Elle a maintenant des sections dans les principales villes américaines, bientôt à Toronto et ailleurs au Canada. Truands repentis ou embryon d'une organisation para-militaire privée? 
Le spectacle commence. "Une" victime, "un" agresseur. La peur. Sur la scène et dans la rue, des groupes se forment pour soutenir la victime. Au troisième balcon, on parle déjà de s'unir pour lui venir en aide. Ailleurs, on chuchote qu'il faut cesser d'avoir peur la nuit...

Et, pendant ce temps, dans les loges, les critiques avec leurs billets gratuits et leurs feuillets dans les revues de la nation, les criminologues et les juristes évaluent, soupèsent, analysent. Les régisseurs écouteront peut-être si, d'aventure, le public venait moins nombreux, mais on sait que ce n'est jamais la critique qui fait ou défait le spectacle.

Le Box office en sait quelque chose. 